\title{
Isolation and characterization of temperature-sensitive mutants of Streptomyces coelicolor A3(2) blocked in macromolecular synthesis
}

\author{
Fiona Flett, * Jacqueline Platt and Stephen G. Oliver \\ Department of Biochemistry and Applied Molecular Biology, University of Manchester Institute of Science and Technology, \\ PO Box 88, Manchester M60 1QD, UK
}

(Received 30 September 1991; revised 12 November 1991; accepted 22 November 1991)

\begin{abstract}
A collection of temperature-sensitive mutants of Streptomyces coelicolor A3(2) was isolated. The majority of the mutants showed an osmotically remedial phenotype. Mutants defective in macromolecular synthesis were identified and characterized further. Four mutants were found in which DNA replication was defective, but which continued to synthesize RNA and protein at the restrictive temperature $\left(39^{\circ} \mathrm{C}\right)$. The kinetics of cessation of DNA synthesis allowed a tentative identification of slow (initiation) and fast (elongation) stop dna mutants. The inhibition of DNA replication in the four mutants was found to be reversible on returning to the permissive temperature $\left(30^{\circ} \mathrm{C}\right)$, but only after a delay of about $2 \mathrm{~h}$. Three other mutants were identified which showed not only cessation of DNA replication at the restrictive temperature, but also defects in other macromolecular synthesis events.
\end{abstract}

\section{Introduction}

One approach to the study of essential cell functions is to use conditional-lethal mutants. The isolation of mutants which are defective in DNA synthesis in some restrictive environment, usually high temperature, was a prerequisite for the analysis of the complex events of DNA replication and the cell division cycle of $E$. coli (reviewed by McMacken et al., 1987). More recently, a similar strategy has been applied to investigate the novel problems posed by Caulobacter crescentus, a bacterium which undergoes cell differentiation; temperature-sensitive DNA replication and cell division mutants have been used to investigate the central role of the cell cycle in controlling morphogenesis (Newton \& Ohta, 1990).

Our interest lies in the streptomycetes, a group of bacteria which have a complex life cycle exhibiting both morphological and metabolic differentiation. A substrate mycelium of branching hyphae, which results from vegetative growth, gives rise to aerial mycelium which subsequently forms spores. Aerial hypha formation is accompanied by physiological changes, in particular the production of a number of secondary metabolites.

Morphological and physiological differentiation appear to be temporally coordinated, and may be initiated in response to nutrient limitation (Braña \& Demain, 1988; de los Reyes-Gavilan et al., 1991). Evidence for

\footnotetext{
*Author for correspondence. Tel. (061) 2363311 ; fax (061) 2360409.
}

such interlinked regulation has come additionally from the study of pleiotropic mutants (bld and afs mutants) which are defective in sporulation and antibiotic production (reviewed by Chater, 1989).

It is an over-simplification to state that there is a clear demarcation between primary growth and the secondary metabolic phase in Streptomyces. However, since one criterion for primary growth of bacteria is an increase in cellular DNA content, it has been proposed that the cessation of DNA replication marks the end of this phase (Martin \& Demain, 1980), at least in liquid culture. Defining the mechanisms that control chromosome replication may be important in understanding the onset of morphological and biochemical differentiation in Streptomyces.

Another challenging aspect of studying the control of DNA replication in Streptomyces is related to the mycelial nature of this organism. The branching hyphae are the result of growth without cell separation. Septa are not abundant, and each compartment of the vegetative hyphae contains multiple copies of the chromosome (Prosser et al., 1988); only the spores contain a single copy. This can be compared with events in $E$. coli, in which the cell cycle involves coordinated DNA replication, cell division and separation (Von Meyenburg \& Hansen, 1987).

In the case of Streptomyces, our knowledge of macromolecular synthesis in general, and DNA replication in particular, is limited (Granozzi et al., 1990). 
Moreover, the available data are mainly concerned with events occurring during spore germination (Hardisson et al., 1980). Our long term objective is to gain an understanding of the control of DNA replication in Streptomyces coelicolor A3(2), genetically the best characterized streptomycete (Hopwood et al., 1985). In this report we describe the isolation and characterization of a number of temperature-sensitive mutants of $S$. coelicolor which are defective in macromolecular synthesis.

\section{Methods}

Bacterial strains. Streptomyces coelicolor A3(2) strain MT1110 was used for the isolation of the ts mutants. This strain (isolated in this laboratory) is an SCP1-, SCP2- derivative of the wild-type prototrophic strain 1147 (Hopwood, 1959).

Growth media and culture conditions. Mannitol soya agar medium (MS) was used to prepare spore stocks as described by Hobbs $e t$ al. (1989). Auxotrophic mutants were detected using minimal medium (Hopwood et al., 1985). Oxoid nutrient agar was used when screening colonies for the ts phenotype. Difco nutrient agar, which contains no added $\mathrm{NaCl}$, was chosen for testing the osmotic remediality of the ts mutants. The measurement of the uptake of radiolabelled compounds was carried out using liquid cultures in YPGS and YPG, which are modified YEME media (Hopwood et al., 1985). YPGS (3 $\mathrm{g}^{-1}$ Difco yeast extract, $5 \mathrm{~g}^{-1}$ Difco Bacto-peptone, $10 \mathrm{~g} \mathrm{l}^{-1}$ glucose and $25 \%$ sucrose, $w / v)$ was used for the non-osmotic remedial mutants and YPG (YPGS lacking sucrose) for the osmotic remedial mutants.

The standard growth temperature was $30^{\circ} \mathrm{C}$. A permissive temperature of $30^{\circ} \mathrm{C}$ and a restrictive temperature of $39^{\circ} \mathrm{C}$ were used when screening for the ts mutants.

Mutagenesis and isolation of ts and auxotrophic mutants. Spores of strain MT1110 were treated with $N$-methyl- $N$-nitro- $N$-nitrosoguanidine (NTG) at a concentration of $2 \mathrm{mg} \mathrm{ml}^{-1}$ at $\mathrm{pH} 8$ (Hopwood et al., 1985). Single colonies arising from mutated spores were grown to sporulation at $30^{\circ} \mathrm{C}$ on MS then 'tooth-picked' onto the appropriate test media. Duplicate Petri dishes were incubated at $30^{\circ} \mathrm{C}$ and $39^{\circ} \mathrm{C}$; colonies which failed to grow at $39^{\circ} \mathrm{C}$ but grew at $30^{\circ} \mathrm{C}$ were rechecked. The putative ts mutants were subjected to two further rounds of single colony isolation, sporulation and temperaturesensitivity testing before being designated as ts mutants. Auxotrophic mutants were screened at $30^{\circ} \mathrm{C}$.

Measurement of macromolecular synthesis. DNA, RNA and protein syntheses were monitored by measuring, respectively, the incorporation into acid-insoluble material of [methyl- ${ }^{3} \mathrm{H}$ ]thymidine [specific activity $40 \mathrm{Ci} \mathrm{mmol}^{-1}\left(1.48 \mathrm{TBq} \mathrm{mmol}{ }^{-1}\right) ; 1.0 \mu \mathrm{Ci} \mathrm{ml}^{-1}$ in the growth medium], $\left[2{ }^{-14} \mathrm{C}\right]$ uracil [specific activity $55 \mathrm{mCi} \mathrm{mmol}^{-1}(2.04 \mathrm{GBq}$ mmol$\left.{ }^{-1}\right) ; 100 \mathrm{nCi} \mathrm{ml}^{-1}$ in the growth medium] and $\left[{ }^{35} \mathrm{~S}\right]$ methionine [specific activity $1000 \mathrm{Ci} \mathrm{mol}^{-1}\left(37 \mathrm{TBq} \mathrm{mmol}^{-1}\right) ; 1.0 \mu \mathrm{Ci} \mathrm{m}^{-1}$ in the growth medium].

Spores were inoculated into $250 \mathrm{ml}$ baffled flasks containing $50 \mathrm{ml}$ liquid medium (YPGS or YPG) supplemented with the required radioactive precursors and incubated at $30^{\circ} \mathrm{C}$ on an orbital shaker. Growth was monitored as $\mathrm{OD}_{600}$ (Cecil spectrophotometer); the temperature shift was carried out when cultures reached $\mathrm{OD}_{600}=0.02$ 0.05 . At this stage, flasks were transferred to a $39^{\circ} \mathrm{C}$ water bath for $15 \mathrm{~min}$, with shaking (the culture reached a temperature of $39^{\circ} \mathrm{C}$ after approximately $5 \mathrm{~min}$ ), and were then placed in a $39^{\circ} \mathrm{C}$ orbital shaker.

To measure the radioactive incorporation, four $0.5 \mathrm{ml}$ samples were taken at each time point, the samples being dealt with as two pairs. One pair was added to $0.5 \mathrm{ml}$ aliquots of cold $10 \%(\mathrm{w} / \mathrm{v})$ trichloroacetic acid (TCA) and cooled on ice for $2 \mathrm{~h}$ then washed (see below). The other samples were added to $0.5 \mathrm{ml}$ aliquots of $2 \mathrm{M}-\mathrm{NaOH}$ and incubated overnight at $37^{\circ} \mathrm{C}$. After incubation, $0.5 \mathrm{ml}$ cooled $50 \%(\mathrm{w} / \mathrm{v})$ TCA was added, and the samples cooled on ice for $2 \mathrm{~h}$ before washing. All the samples were washed with cold $5 \%(w / v)$ TCA on glass-fibre filters (Whatman GF/C). After drying the filters, the radioactivity in the acidinsoluble fraction was counted in a RackBeta II liquid scintillation counter (LKB) using Optiphase 'Hisafe' 3 scintillation fluid (LKB). The data on the incorporation of $\left[{ }^{3} \mathrm{H}\right]$ thymidine into DNA were derived from $\mathrm{NaOH}$-treated samples, whereas the data for $\left.{ }^{35} \mathrm{~S}\right]$ methionine and protein were derived from non- $\mathrm{NaOH}$-treated samples. Data on $\left[{ }^{14} \mathrm{C}\right]$ uracil incorporation into RNA were obtained by subtracting the c.p.m. in $\mathrm{NaOH}$-treated samples from the c.p.m. in non- $\mathrm{NaOH}$-treated samples. Each experiment was carried out at least three times to confirm the reproducibility of the results shown. All the radioactive compounds were obtained from Amersham International.

\section{Results and Discussion}

\section{Isolation of temperature-sensitive (ts) mutants}

All of the mutants described here were obtained by $\mathrm{N}$ methyl- $N^{\prime}$-nitro- $N$-nitrosoguanidine treatment of spores. 50000 spore clones, which grew at the permissive temperature of $30^{\circ} \mathrm{C}$, were screened for ts growth at $39^{\circ} \mathrm{C}$ and/or auxotrophy at $30^{\circ} \mathrm{C} .102$ mutants which were ts on nutrient agar were identified. This frequency $(0.2 \%)$ was comparable to the observed frequency of non-ts auxotrophs in this experiment $(0.3 \%)$.

\section{Growth medium suppression of ts phenotype}

The temperature-sensitive phenotype of these mutants was tested on several different media. No differences were observed between minimal and complex media; however, on the addition of sucrose $(25 \%, \mathrm{w} / \mathrm{v})$ to the media, only 12 of the 102 ts mutants failed to grow at $39{ }^{\circ} \mathrm{C}$. Replacement of the sucrose with iso-osmolar $\mathrm{KCl}$ $(4.1 \%, w / v)$ gave similar results. The ability of sucrose or $\mathrm{KCl}$ to suppress the ts phenotype suggests that the majority of the ts mutants are osmotically remedial. Osmotic suppression occurs with ts mutants of many bacteria and fungi (reviewed by Csonka, 1989), including ts dna mutants of E. coli (Chu et al., 1977; Ricard \& Hirota, 1969). This remediality probably reflects the fact that the structures of such mutant proteins are unusually sensitive to the solute composition of the cytoplasm, which is in part determined by the external osmolarity.

During the course of the media testing, it was noted that $48 \mathrm{~h}$ growth at $30^{\circ} \mathrm{C}$ in the presence of $\mathrm{KCl}$ or sucrose resulted in enhanced production of the red pigment, undecylprodigiosin, when compared with the results obtained on non-supplemented solid media. This phenomenon was apparent with the parent strain as well as the mutants. It is likely that the overproduction of 
undecylprodigiosin is due to a 'proline effect'. Measures (1975) found that osmotic stress resulted in large increases in the intracellular levels of proline in a variety of bacteria; more recently, this has been shown with Streptomyces griseus as well (Killham \& Firestone, 1984). A study of the synthesis, uptake and breakdown of proline by $S$. coelicolor has demonstrated that the intracellular concentration of this amino acid can directly influence the level of synthesis of undecylprodigiosin; excess proline can be shunted into the production of this secondary metabolite (D. A. Hodgson, personal communication). Thus a high salt concentration in the growth medium may result in the intracellular accummulation of proline and enhanced production of undecylprodigiosin.

\section{Identification of macromolecular synthesis mutants}

In order to identify any mutants defective in macromolecular synthesis, liquid culture experiments were carried out at the permissive and restrictive temperatures to follow the incorporation of $\left[{ }^{3} \mathrm{H}\right]$ thymidine, $\left[{ }^{14} \mathrm{C}\right]$ uracil and ${ }^{35}$ S $]$ methionine into DNA, RNA and protein, respectively.

\section{DNA synthesis mutants}

Four mutants were found in which DNA replication is defective, but which continue to synthesize RNA and protein at $39^{\circ} \mathrm{C}$. None showed a cold-sensitive growth phenotype at $20^{\circ} \mathrm{C}$. In ts-38, a non-osmotically remedial ts mutant, the incorporation of $\left[{ }^{3} \mathrm{H}\right]$ thymidine into DNA continued for $2 \mathrm{~h}$ after the shift from $30^{\circ} \mathrm{C}$ to $39^{\circ} \mathrm{C}$ but then ceased, whereas the incorporation of $\left[{ }^{14} \mathrm{C}\right]$ uracil and $\left[{ }^{35} \mathrm{~S}\right]$ methionine proceeded for at least $5 \mathrm{~h}$ after switching to the restrictive temperature (Fig. 1a). Cessation of DNA synthesis was not observed in cultures maintained at $30^{\circ} \mathrm{C}$ (data not shown). The effect of the culture temperature on DNA synthesis of the wild-type strain in YPGS media is shown in Fig. 1(b). The doubling time of the wild-type strain in this medium at $39^{\circ} \mathrm{C}$ is about $90 \mathrm{~min}$. The growth kinetics of ts-38 in YPGS medium were also monitored by optical density readings; the $\mathrm{OD}_{600}$ continued to increase for a minimum of $5 \mathrm{~h}$ after transfer to the restrictive temperature. This pattern of cessation of DNA replication has been described as 'slow stop' for ts mutants of other bacterial species (Hirota et al., 1970; Wechsler \& Gross, 1971) and implies that ts-38 may be defective in the initiation of DNA replication. Samples of YPGS cultures of the wildtype parent and ts-38 were examined by phase contrast microscopy. Two hours after the switch to $39^{\circ} \mathrm{C}$, the mycelium of both strains exhibited an increased frequency of branching as compared to that seen in $30^{\circ} \mathrm{C}$ cultures.
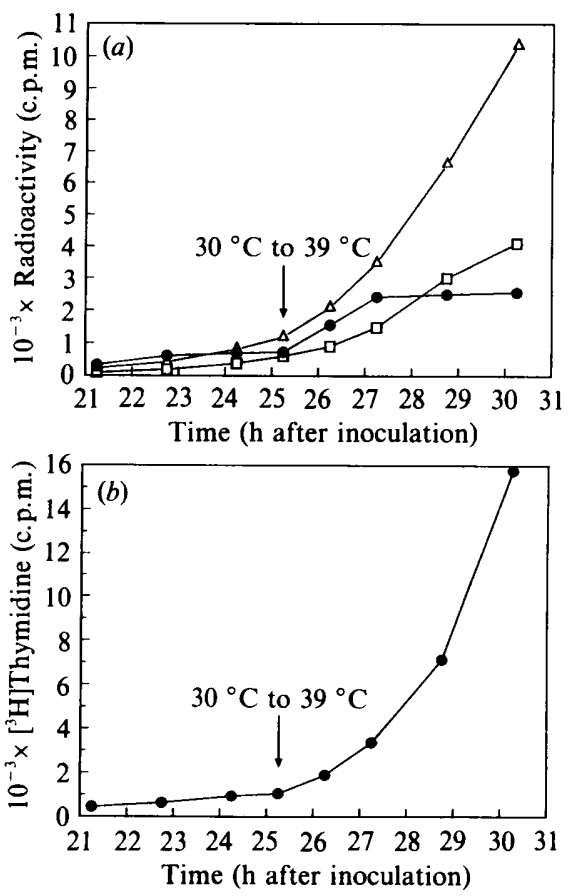

Fig. 1. Macromolecular synthesis of ts-38 and the parent strain MT1110. Spores were inoculated into YPGS medium containing the specified radiolabelled compounds at $30^{\circ} \mathrm{C}$. Cultures were shifted to $39^{\circ} \mathrm{C}$ as indicated. Incorporation of the radiolabelled compounds into TCA-precipitable material was determined. (a) ts-38:,$\left[{ }^{3} \mathrm{H}\right]$ thymidine; $\square,\left[{ }^{14} \mathrm{C}\right]$ uracil; and $\triangle,\left[{ }^{35}\right.$ S $]$ methionine. (b) MT1110: $\left[{ }^{3} \mathrm{H}\right]$ thymidine.

The three other ts DNA replication mutants isolated in this study (ts-66, ts-102 and ts-114) all showed an osmotic remedial ts phenotype, necessitating the use of media without sucrose (YPG) for the labelling studies. Initial experiments determined whether the temperature shift to $39^{\circ} \mathrm{C}$ had any observable effect on DNA replication of the wild-type strain in YPG medium. After the switch to $39^{\circ} \mathrm{C}$, DNA synthesis was found to be impaired for up to $3 \mathrm{~h}$, then the incorporation of $\left[{ }^{3} \mathrm{H}\right]$ thymidine started to increase again as in the $30^{\circ} \mathrm{C}$ control culture (Fig. 2). Similar results were obtained in experiments monitoring protein synthesis. This behaviour may reflect a heat shock response by the organism. In a recent study, E. Barratt (personal communication) has demonstrated that a high sucrose concentration in the medium protects $S$. lividans against the effects of thermal shock. It seems possible that this effect, like the suppression of the ts mutations, is due to a decreased level of protein denaturation at high osmotic pressures.

Labelling studies on ts-66 showed that $\left[{ }^{3} \mathrm{H}\right]$ thymidine incorporation stopped within $20 \mathrm{~min}$ of raising the temperature to $39^{\circ} \mathrm{C}$, and there was also some evidence of a net decrease in DNA content (Fig. 3a). RNA and protein synthesis continued for approximately $3 \mathrm{~h}$ then 


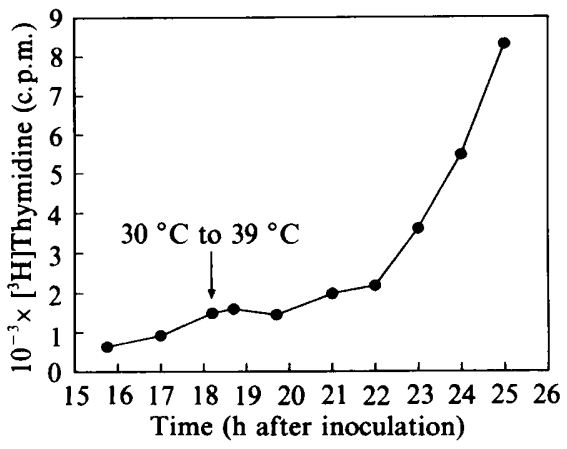

Fig. 2. DNA synthesis of the parent strain MT1110. Spores were inoculated into YPG medium containing $\left[{ }^{3} \mathrm{H}\right]$ thymidine at $30^{\circ} \mathrm{C}$. The culture was shifted to $39^{\circ} \mathrm{C}$ as indicated. Incorporation of $\left[{ }^{3} \mathrm{H}\right]$ thymidine into TCA-precipitable material was determined.
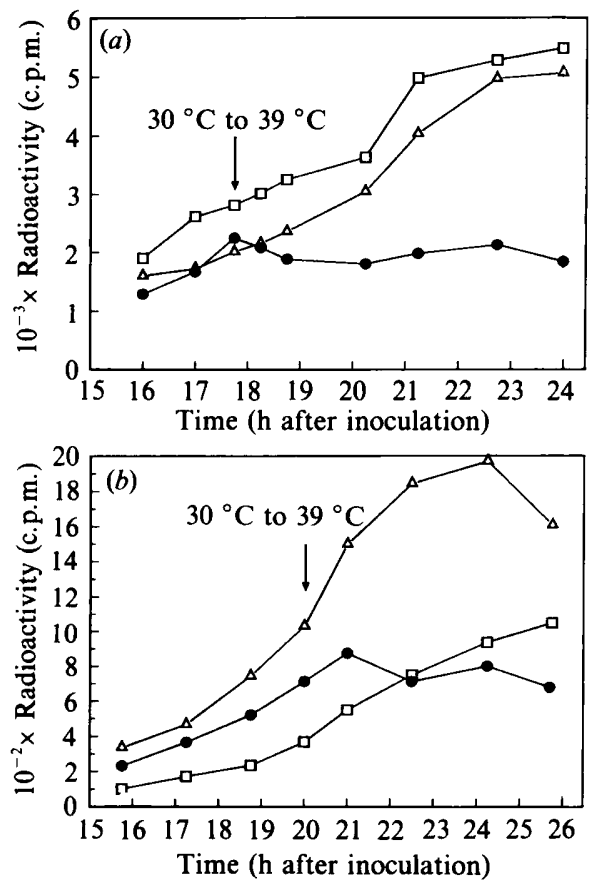

Fig. 3. Macromolecular synthesis of $(a)$ ts-66 and $(b)$ ts-102. Spores were inoculated into YPG medium containing $\bigcirc,\left[{ }^{3} \mathbf{H}\right]$ thymidine; $\square$, $\left[{ }^{14} \mathrm{C}\right]$ uracil; or $\triangle,\left[{ }^{35} \mathrm{~S}\right]$ methionine at $30^{\circ} \mathrm{C}$; cultures were shifted to $39^{\circ} \mathrm{C}$ as indicated. Incorporation of the radiolabelled compounds into TCA-precipitable material was determined.

the incorporation of $\left[{ }^{14} \mathrm{C}\right]$ uracil and $\left[{ }^{35} \mathrm{~S}\right]$ methionine levelled off. $\left[{ }^{3} \mathrm{H}\right]$ Thymidine incorporation continued for about 30 min after switching ts- 114 to $39^{\circ} \mathrm{C}$. Protein and RNA were synthesized for a few hours, but at a reduced linear rate.

The kinetics of cessation of DNA synthesis observed for ts-66 and ts- 114 contrasts with those for ts-38 and we propose, by analogy with other systems (Wechsler \&
Gross, 1971), that the former two mutants are defective in the elongation step of DNA replication. The pattern of macromolecular synthesis shown by these mutants is markedly different from that of the ts mutant of Streptomyces hygroscopicus described by Süss et al. (1988), which showed an immediate cessation of both DNA and RNA synthesis on transfer to the restrictive temperature.

In the fourth mutant, ts-102, DNA synthesis continued for about an hour after transfer to the restrictive temperature, then stopped. The incorporation of ${ }^{35}$ S]methionine was maintained for $2.5 \mathrm{~h}$, and that of $\left[{ }^{14} \mathrm{C}\right]$ uracil for about $3.5 \mathrm{~h}$ before reaching a plateau (Fig. $3 b$ ). This mutant exhibits a phenotype which is intermediate between those of ts-38 and ts-66, and the nature of the lesion in DNA replication is unclear. E. coli ts mutants collected by Kohiyama et al. (1966) also contained examples with such behaviour. The mutation in ts-102 appears to have an effect independent of temperature, since the doubling time of this strain in YPG at $30^{\circ} \mathrm{C}$ was about $100 \mathrm{~min}$, whereas under the same growth conditions the wild-type, ts- 66 and ts-114 had doubling times of about $80 \mathrm{~min}$.

The absence of sucrose, which is used to produce more dispersed growth, from the liquid medium YPG made detailed microscopic examination of the cultures problematic. Moreover, after transfer to the restrictive temperature, the mycelium of these three ts mutants formed dense clumps, whereas in the $30^{\circ} \mathrm{C}$ control cultures, the mycelium formed loose clumps with numerous freely extending hyphae. The wild-type strain underwent a similar but transient morphological response to the increased temperature, which corresponded to the period of impaired macromolecular synthesis described above. After about $3 \mathrm{~h}$ at $39^{\circ} \mathrm{C}$, the appearance of the mycelium 'reverted' to that of the $30^{\circ} \mathrm{C}$ culture.

In Streptomyces, hyphal extension occurs by tip growth (Prosser et al., 1988), whereas DNA synthesis appears to take place throughout the vegetative mycelium (Kummer \& Kretschmer, 1986; Prosser et al., 1988). Aggregations of nucleoids increase in frequency and size with increasing distance from the hyphal tip and they occur close to branching points, supplying lateral branches with nucleoids (Kretschmer, 1987; Prosser et al., 1988). Correct segregation of nucleoids into branches would appear to be essential if exponential growth of the organism is to be maintained. Understanding mycelial growth and the development of a regulated branching mycelium requires knowledge of the mechanisms controlling cell wall synthesis, septation, branching and normal DNA replication in Streptomyces; the ts DNA synthesis mutants described here may be useful in this context. 


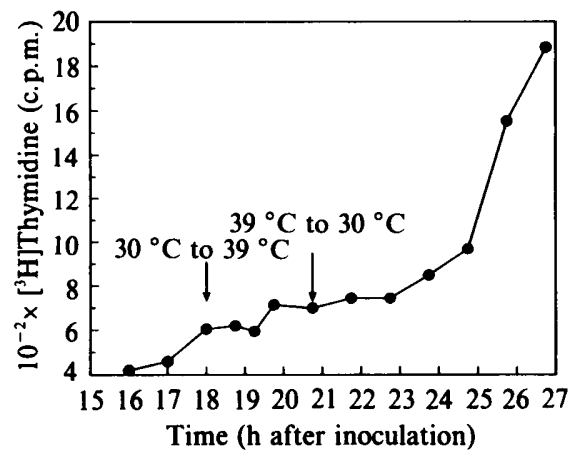

Fig. 4. Reinitiation of DNA synthesis of ts-66 on return to the permissive temperature. Spores were inoculated into YPG medium containing $\left[{ }^{3} \mathrm{H}\right]$ thymidine at $30^{\circ} \mathrm{C}$; the culture was shifted to $39^{\circ} \mathrm{C}$ for approx. $3 \mathrm{~h}$, then returned to $30^{\circ} \mathrm{C}$ as indicated. The incorporation of [ $\left.{ }^{3} \mathrm{H}\right]$ thymidine into TCA-precipitable material was determined.

\section{Double temperature shift experiments}

Double temperature shift experiments were undertaken to determine whether or not the block in DNA synthesis observed in the four ts mutants was reversible. Cultures were incubated at $30^{\circ} \mathrm{C}$ for $18 \mathrm{~h}$, transferred to $39^{\circ} \mathrm{C}$ for $3 \mathrm{~h}$ and then returned to $30^{\circ} \mathrm{C}$. The inhibition of DNA replication in all four mutants was found to be reversible on returning to the permissive temperature, but only after a delay of about $2 \mathrm{~h}$. Fig. 4 shows the effect for mutant ts-66. The majority of DNA initiation mutants of $E$. coli show a delayed resumption of DNA synthesis in the same type of experiments (Hanna \& Carl, 1975); the results with ts-38 are thus comparable. However, ts-66 and ts-114 did not show the rapid reinitiation of DNA synthesis which is typical of $E$. coli DNA elongation mutants (Chu et al., 1977); instead DNA replication recommenced about $2 \mathrm{~h}$ after the return to the permissive temperature.

Data from double temperature shift regimes are potentially important when considering reciprocal shift experiments which can provide insight into the timing and hierarchy of successive cell cycle events. This concept was developed by Hereford \& Hartwell (1974) in their analysis of the yeast cell cycle, and has been applied subsequently to Caulobacter crescentus. Osley \& Newton (1980) examined how the steps required for DNA replication and cell division, which appear to regulate differentiation in Caulobacter, are temporally controlled and organized. In the case of $S$. coelicolor, our aim would be to use reciprocal shift experiments to probe the possible inter-relationships between the control of DNA replication, the cell cycle and secondary metabolite formation.
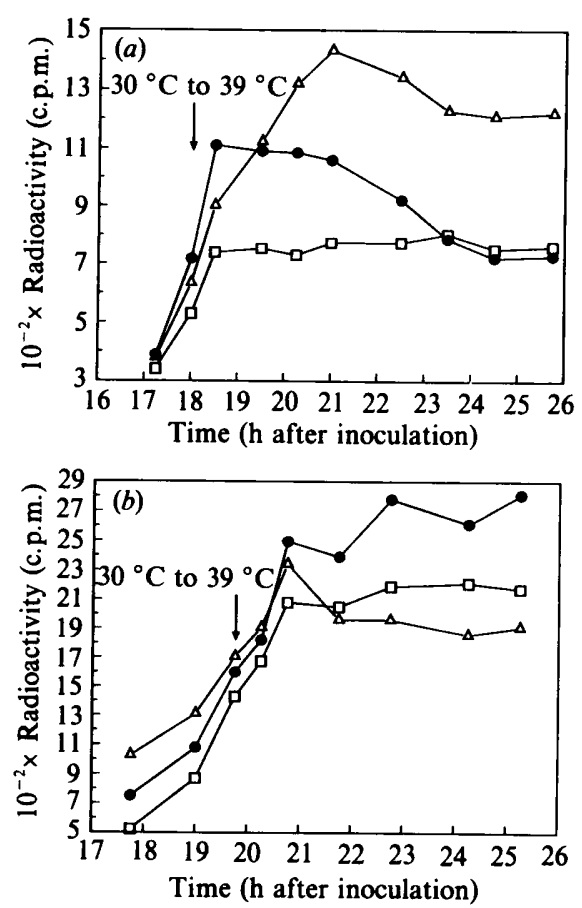

Fig. 5. Macromolecular synthesis of $(a)$ ts- 98 and $(b)$ ts -45 . Spores were inoculated into YPG medium containing $O,\left[{ }^{3} \mathrm{H}\right]$ thymidine; $\square$, $\left[{ }^{14} \mathrm{C}\right]$ uracil or $\triangle,\left[{ }^{35} \mathrm{~S}\right]$ methionine at $30^{\circ} \mathrm{C}$; the culture was shifted to $39^{\circ} \mathrm{C}$ as indicated. Incorporation of the radiolabelled compounds into TCA-precipitable material was determined.

\section{Macromolecular synthesis mutants with more complex phenotypes}

Three other mutants were identified which showed not only cessation of DNA replication at the restrictive temperature, but also defects in other macromolecular synthesis events.

In the case of ts-98, incorporation of $\left[{ }^{3} \mathrm{H}\right]$ thymidine and $\left[{ }^{14} \mathrm{C}\right]$ uracil stopped after $30 \mathrm{~min}$ at $39^{\circ} \mathrm{C}$, whereas $\left.{ }^{[35} \mathrm{S}\right]$ methionine incorporation continued for $3 \mathrm{~h}$, although at a reduced rate (Fig. 5a). One possible interpretation is that ts-98 is the equivalent of a dnaK mutant since these labelling kinetics are similar to those observed with a ts dnaK mutant of $E$. coli (Itikawa \& Ryu, 1979).

Ts-60 showed rapid cessation of protein and RNA synthesis (within $15 \mathrm{~min}$ of transfer to $39^{\circ} \mathrm{C}$ ), DNA synthesis continued for about $1 \mathrm{~h}$ (data not shown). The most likely classification of ts-60 is as an RNA synthesis mutant, perhaps with the mutation affecting RNA polymerase (Ishihama et al., 1980). However when ts-60 was tested in a double temperature shift experiment, no reversibility of the inhibition of macromolecular synthesis was observed, even $6 \mathrm{~h}$ after a return to $30^{\circ} \mathrm{C}$. This pattern does not correspond to that obtained with $E$. coli RNA polymerase mutants, which show a rapid recovery 
Table 1. Properties of ts macromolecular synthesis mutants of $S$. coelicolor

\begin{tabular}{|c|c|c|c|c|c|}
\hline \multirow[b]{2}{*}{ Mutant } & \multirow{2}{*}{$\begin{array}{l}\text { Osmotically } \\
\text { remedial }\end{array}$} & \multicolumn{3}{|c|}{ Patterns of macromolecular synthesis at $39^{\circ} \mathrm{C}$} & \multirow{2}{*}{$\begin{array}{l}\text { Possible lesion by } \\
\text { analogy with } E \text {. coli }\end{array}$} \\
\hline & & DNA & RNA & Protein & \\
\hline 38 & No & Stops after $2 \mathrm{~h}$ & Continues for $5 \mathrm{~h}$ & Continues for $5 \mathrm{~h}$ & DNA initiation \\
\hline 66 & Yes & Stops within $20 \mathrm{~min}$ & Continues for $3 \mathrm{~h}$ & Continues for $3 \mathrm{~h}$ & DNA elongation \\
\hline 102 & Yes & Stops after $1 \mathrm{~h}$ & Continues for $3.5 \mathrm{~h}$ & Continues for $2.5 \mathrm{~h}$ & DNA replication \\
\hline 114 & Yes & Stops after $30 \mathrm{~min}$ & Continues for $2.5 \mathrm{~h}$ & Continues for $2.5 \mathrm{~h}$ & DNA elongation \\
\hline 45 & Yes & Stops after $1 \mathrm{~h}$ & Stops after $1 \mathrm{~h}$ & Stops after $1 \mathrm{~h}$ & $a d k$-like \\
\hline 60 & Yes & Continues for $1 \mathrm{~h}$ & Stops within $15 \mathrm{~min}$ & Stops within $15 \mathrm{~min}$ & RNA synthesis \\
\hline 98 & Yes & Stops after $30 \mathrm{~min}$ & Stops after $30 \mathrm{~min}$ & Continues for $3 \mathrm{~h}$ & dnaK-like \\
\hline
\end{tabular}

of RNA synthesis on transfer to the permissive temperature (Yoshinaga \& Sugiura, 1977). The lack of reversibility of the ts-60 RNA synthesis lesion after transfer from restrictive to permissive temperatures was reflected in a loss of viability. The ability to form colonies on nutrient agar at $30^{\circ} \mathrm{C}$ declined ten fold after $3 \mathrm{~h}$ exposure to $39^{\circ} \mathrm{C}$; such a loss of viability was not observed with the ts DNA synthesis mutants.

In temperature shift experiments on ts- 45 , synthesis of DNA, RNA and protein stopped after an hour at $39^{\circ} \mathrm{C}$ (Fig. $5 b$ ). Incorporation of $\left[{ }^{14} \mathrm{C}\right]$ uracil into RNA resumed rapidly on return to $30^{\circ} \mathrm{C}$, whereas DNA and protein synthesis were not reinitiated within $3 \mathrm{~h}$ of transfer to the permissive temperature. The apparently simultaneous cessation of DNA, RNA and protein synthesis may point to a mutation in an energygenerating system rather than directly in one of the macromolecular synthesis pathways. Another possibility is that ts-45 is similar to the dnaW mutant of $E$. coli (Blinkowa \& Gawecka, 1979), although the latter exhibits much more rapid inhibition of macromolecular synthesis at $42{ }^{\circ} \mathrm{C}$. The $d n a W$ mutation has been shown subsequently to be an allele of the adk (adenylate kinase) gene (Henson et al., 1982). Interestingly, double temperature shift experiments with the $d n a W$ mutant produced reinitiation results similar to those obtained with ts -45 ; i.e. RNA synthesis started rapidly on transfer to $30^{\circ} \mathrm{C}$, but the inhibition of DNA and protein synthesis was reversible only after a long delay (Blinkowa \& Gawecka, 1979).

Clearly, further analysis of these three mutants will be required before their specific lesions can be identified and this may have to await the accumulation of more data concerning the primary metabolism of Streptomyces.

\section{Conclusions}

We believe this to be the first report of the isolation and preliminary characterization of a set of ts macromolecular synthesis mutants of $S$. coelicolor. The properties of these mutants are summarized in Table 1. Hopwood (1966) reported the isolation of ts mutants of $S$. coelicolor for gene mapping purposes; auxotrophic and 'indispensable' ts mutants were identified but the latter were not characterized further. More recently, a single ts $d n a$ mutant of $S$. hygroscopicus has been described (Süss et al., 1988), but the rapid cessation of both DNA and RNA synthesis at the restrictive temperature is evidently different from the patterns observed with the four mutants which we have classified as dna mutants. These $S$. coelicolor ts mutants have considerable potential as tools for the study of many areas of streptomycete molecular biology. By analogy with other micro-organisms (McMacken et al., 1987; Newton \& Ohta, 1990), they should prove useful in elucidating the regulation of macromolecular synthesis. DNA replication and its possible involvement in the control of secondary metabolite production are primary targets for such studies. The tentative identification of both slow (initiation) and fast (elongation) stop mutants should facilitate the cloning of some of the essential genes required for DNA replication in $S$. coelicolor. Future work will also include an investigation of plasmid replication in the dna mutants, and probing of possible integrative suppression events arising from interactions between the Streptomyces chromosome and the large linear plasmid SCP1.

This research was supported by the 'Antibiotics and Recombinant DNA' initiative, which was sponsored by the SERC Biotechnology Directorate, the Department of Trade and Industry, Beecham Pharmaceuticals, Celltech, Glaxo Group Research and ICI Pharmaceuticals. We wish to acknowledge the major contribution which John Cullum made to the initiation of this project. We are grateful to Paul Broda and Colin Smith for many useful discussions and to David Hodgson for the communication of data prior to publication. We also thank the other members of the research group who acted as 'colony pickers'.

\section{References}

BlinkowA, A. \& GAWECKA, G. (1979). Mechanism of conjugation II. Characterization of an Hfr dna ts mutant of Escherichia coli K-12. Molecular and General Genetics 172, 107-111. 
Braña, A. F. \& Demain, A. L. (1988). Nitrogen source control of antibiotic biosynthesis in actinomycetes. In Nitrogen Source Control of Microbial Processes, pp. 99-119. Edited by S. Sanchez Esquivel. Boca Raton, Florida: CRC Press.

Chater, K. F. (1989). Sporulation in Streptomyces. In Regulation of Procaryotic Development, pp. 277-299. Edited by I. Smith, R. A. Slepecky \& P. Setlow. Washington, DC: American Society for Microbiology.

Chu, H., Malone, M. M., Haldenwang, W. G. \& Walker, J. R. (1977). Physiological effects of growth of an Escherichia coli temperature-sensitive $d n a Z$ mutant at nonpermissive temperatures. Journal of Bacteriology 132, 151-158.

CsonkA, L. N. (1989). Physiological and genetic responses of bacteria to osmotic stress. Microbiological Reviews 53, 121-147.

Granozzi, C., Billetta, R., Passantino, R., Sollazzo, M. \& PugliA, A. M. (1990). A breakdown in macromolecular synthesis preceding differentiation in Streptomyces coelicolor A3(2). Journal of General Microbiology 136, 713-716.

HanNa, M. H. \& CARL, P. (1975). Reinitiation of deoxyribonucleic acid synthesis by deoxyribonucleic acid initiation mutants of Escherichia coli: role of ribonucleic acid synthesis, protein synthesis and cell division. Journal of Bacteriology 121, 219-226.

Hardisson, C., Salas, J. A., Guijarro, J. A. \& Súarez, J. E. (1980). Macromolecular synthesis during the germination of Streptomyces spores in a chemically defined medium. FEMS Microbiology Letters 7, 233-235.

Henson, J. M., Blinkowa, A.\& Walker, J. R. (1982). The Escherichia coli dnaW mutation is an allele of the adK gene. Molecular and General Genetics 186, 488-492.

HEREFORD, L. M. \& HARTWELl, L. H. (1974). Sequential gene function in the initiation of Saccharomyces cerevisiae DNA synthesis. Journal of Molecular Biology 84, 445-461.

Hirota, Y., MORDOH, J. \& JACOB, F. (1970). On the process of cell division in Escherichia coli. III. Thermosensitive mutants of Escherichia coli altered in the process of DNA initiation. Journal of Molecular Biology 53, 422-431.

Hobrs, G., Frazer, C. M., Gardner, D. C. J., Cullum, J. A. \& OLIVER, S. G. (1989). Dispersed growth of Streptomyces in liquid culture. Applied Microbiology and Biotechnology 31, 272-277.

HoPwOOD, D. A. (1959). Linkage and the mechanism of recombination in Streptomyces coelicolor. Annals of the New York Academy of Sciences 81, 887-898.

HopwOOD, D. A. (1966). Nonrandom location of temperature-sensitive mutants on the linkage map of Streptomyces coelicolor. Genetics 54, 1169-1176.

Hopwood, D. A., BibB, M. J., Chater, K. F., Kieser, T., Bruton, C. J., Lydiate, D. J., SMITH, C. P., WARD, J. M. \& SCHRempF, H. (1985). Genetic Manipulation of Streptomyces - a Laboratory Manual. Norwich, UK : John Innes

ishihama, A., Shimamoto, N., Aiba, H., Kawakami, K., Nashimoto, H., Tsugawa, A. \& UCHIDA, H. (1980). Temperature-sensitive mutations in the subunit gene of Escherichia coli RNA polymerase. Journal of Molecular Biology 137, 137-150.

ITIKAWA, H., \& RYU, J.-I. (1979). Isolation and characterization of a temperature-sensitive dnaK mutant of Escherichia coli B. Journal of Bacteriology 138, 339-344.
Killham, K. \& Firestone, M. K. (1984). Sait stress control of intracellular solutes in streptomycetes indigenous to saline soils. Applied and Environmental Microbiology 47, 301-306.

Kohiyama, M., Cousin, D. Ryter, A. \& JACOB, F. (1966). Mutants thermosensibles d'Escherichia coli $\mathrm{K}-12$. I. Isolement et characterisation rapide. Annales de l'Institut Pasteur 110, 465-486.

KRETSCHMER, S. (1987). Nucleoid segregation pattern during branching in Streptomyces granaticolor mycelia. Journal of Basic Microbiology 27, 203-206.

KUMmer, C. \& KRETSChMER, S. (1986). DNA replication is not restricted to specific regions in young vegetative Streptomyces mycelia. Journal of Basic Microbiology 26, 27-31.

MCMACKen, R., Silver, L. \& Georgopoulos, C. (1987). DNA replication. In Escherichia coli and Salmonella typhimurium: Cellular and Molecular Biology, pp. 564-612. Edited by F. C. Neidhardt, J. L. Ingraham, K. B. Low, B. Magasanik, M. Schaechter \& H. E. Umbarger. Washington, DC: American Society for Microbiology.

Martin, J. F. \& Demain, A. L. (1980). Control of antibiotic biosynthesis. Microbiological Reviews 44, 230-251.

Measures, J. C. (1975). Role of amino acids in osmoregulation of nonhalophilic bacteria. Nature, London 257, 398-400.

Newton, A. \& OHTA, N. (1990). Regulation of the cell division cycle and differentiation in bacteria. Annual Review of Microbiology 44, 689-719.

OsLey, M. A. \& Newton, A. (1980). Temporal control of the cell cycle in Caulobacter crescentus: roles of DNA chain elongation and completion. Journal of Molecular Biology 138, 109-128.

Prosser, J. I., Gray, D. I. \& Gooday, G. W. (1988). Cellular mechanisms for growth and branch formation in streptomycetes. In Biology of Actinomycetes '88, pp. 316-323. Edited by Y. Okami, T. Beppu \& H. Ogawara. Tokyo: Japan Scientific Societies Press.

de los Reyes-Gavilán, C. G., Cal, S., Barbés, C., Hardisson, C. \& SÁNCHEZ, J. (1991). Nutritional regulation of differentiation and synthesis of an exocytoplasmic deoxyriboendonuclease in Streptomyces antibioticus. Journal of General Microbiology 136, 299305.

Ricard, M. \& Hirota, Y. (1969). Effet des sels sur le processus de division cellulaire d'E. coli. Comptes Rendus Acadamie Sciences Paris 268, 1335-1338.

SÜss, F., Frunder, B., Klaus, S. \& Noack, D. (1988). Characterization of a thermosensitive mutant of Streptomyces hygroscopicus defective in both DNA and RNA syntheses. Journal of Basic Microbiology 28, 541-551.

Von Meyenburg, K. \& Hansen, F. G. (1987). Regulation of chromosome replication. In Escherichia coli and Salmonella typhimurium: Cellular and Molecular Biology, pp. 1555-1577. Edited by F. C. Neidhardt, J. L. Ingraham, K. B. Low, B. Magasanik, M. Schaechter \& H. E. Umbarger. Washington, DC: American Society for Microbiology.

WeChSLER, J. A. \& Gross, J. D. (1971). Escherichia coli mutants temperature-sensitive for DNA synthesis. Molecular and General Genetics 113, 273-284.

Yoshinaga, K. \& Sugiura, M. (1977). Physiological studies on a temperature-sensitive Escherichia coli mutant with an altered RNA polymerase $\beta^{\prime}$-subunit. Biochimica et Biophysica Acta 479, 172-179. 